\title{
Moderate and prolonged hypercapnic acidosis may protect against ventilator-induced diaphragmatic dysfunction in healthy piglet: an in vivo study
}

Boris Jung ${ }^{1}$, Mustapha Sebbane ${ }^{2}$, Charlotte Le Goff ${ }^{1}$, Nans Rossel ${ }^{1}$, Gerald Chanques ${ }^{1}$, Emmanuel Futier ${ }^{3}$, Jean-Michel Constantin ${ }^{3}$, Stefan Matecki ${ }^{1}$ and Samir Jaber ${ }^{1^{*}}$

\begin{abstract}
Introduction: Protective ventilation by using limited airway pressures and ventilation may result in moderate and prolonged hypercapnic acidosis, as often observed in critically ill patients. Because allowing moderate and prolonged hypercapnia may be considered protective measure for the lungs, we hypothesized that moderate and prolonged hypercapnic acidosis may protect the diaphragm against ventilator-induced diaphragmatic dysfunction (VIDD). The aim of our study was to evaluate the effects of moderate and prolonged (72 hours of mechanical ventilation) hypercapnic acidosis on in vivo diaphragmatic function.
\end{abstract}

Methods: Two groups of anesthetized piglets were ventilated during a 72-hour period. Piglets were assigned to the Normocapnia group $(n=6)$, ventilated in normocapnia, or to the Hypercapnia group $(n=6)$, ventilated with moderate hypercapnic acidosis $\left(\mathrm{PaCO}_{2}\right.$ from 55 to $70 \mathrm{~mm} \mathrm{Hg}$ ) during the 72-hour period of the study. Every 12 hours, we measured transdiaphragmatic pressure (Pdi) after bilateral, supramaximal transjugular stimulation of the two phrenic nerves to assess in vivo diaphragmatic contractile force. Pressure/frequency curves were drawn after stimulation from 20 to $120 \mathrm{~Hz}$ of the phrenic nerves. The protocol was approved by our institutional animal-care committee.

Results: Moderate and prolonged hypercapnic acidosis was well tolerated during the study period. The baseline pressure/frequency curves of the two groups were not significantly different (Pdi at $20 \mathrm{~Hz}, 32.7 \pm 8.7 \mathrm{~cm} \mathrm{H}_{2} \mathrm{O}$, versus $34.4 \pm 8.4 \mathrm{~cm} \mathrm{H}_{2} \mathrm{O}$; and at $120 \mathrm{~Hz}, 56.8 \pm 8.7 \mathrm{~cm} \mathrm{H}_{2} \mathrm{O}$ versus $60.8 \pm 5.7 \mathrm{~cm} \mathrm{H} \mathrm{H}_{2}$, for Normocapnia and Hypercapnia groups, respectively). After 72 hours of ventilation, Pdi decreased by $25 \%$ of its baseline value in the Normocapnia group, whereas Pdi did not decrease in the Hypercapnia group.

Conclusions: Moderate and prolonged hypercapnic acidosis limited the occurrence of VIDD during controlled mechanical ventilation in a healthy piglet model. Consequences of moderate and prolonged hypercapnic acidosis should be better explored with further studies before being tested on patients.

\section{Introduction}

Mechanical ventilation is a lifesaving technique and a leading treatment of acute respiratory failure in the intensive care unit (ICU). In the earliest stages of acute respiratory failure, maintaining respiratory muscles at rest, in

\footnotetext{
* Correspondence: s-jaber@chu-montpellier.fr

'Intensive Care Unit, Department of Anaesthesia and Critical Care, Saint Eloi Teaching Hospital and Institut National de la Santé et de la Recherche Médicale Unit 1046 (INSERM U-1046), Université Montpellier 1, 34295 Montpellier, France

Full list of author information is available at the end of the article
}

particular the diaphragm, is frequently performed, the better to synchronize the patient and the ventilator. The ventilator settings often use a totally controlled mode and are combined with deep sedation to avoid spontaneous ventilator cycles. One of the consequences of resting respiratory muscles is the occurrence of ventilator-induced diaphragmatic dysfunction (VIDD) [1-3], largely described in animal models and more sparsely, but recently, in human studies [4-8]. Another complication of mechanical ventilation is the occurrence of ventilator-induced lung
C Biomed Central

(c) 2013 Jung et al.; licensee BioMed Central Ltd. This is an open access article distributed under the terms of the Creative Commons Attribution License (http://creativecommons.org/licenses/by/2.0), which permits unrestricted use, distribution, and reproduction in any medium, provided the original work is properly cited. 
injury (VILI), which is magnified when high alveolar pressures and volumes are applied [9], even in healthy lungs $[10,11]$. As a consequence, the historic goal of mechanical ventilation, normalizing the gas exchange, has evolved toward preventing lung injury by reducing alveolar pressure and lung volume, at the cost of reduced gas exchange. This concept, labeled protective ventilation, may lead to a permissive hypercapnic acidosis, which is well tolerated when not so severe $\left(\mathrm{pH}>7.20\right.$ with $\mathrm{PaCO}_{2}<60$ to $65 \mathrm{~mm}$ $\mathrm{Hg}$ ) [12]. Furthermore, some studies have shown a potential beneficial effect of moderate and prolonged hypercapnic acidosis per se on lung inflammation in animal models of experimental pneumonia [13], and it may prevent hypoxia-induced oxydative stress in the lungs [14] and NF- $\kappa \mathrm{B}$ activation in pulmonary endothelial cells exposed to lipopolysaccharide [15]. Hypercapnic acidosis may also inhibit endogenous xanthine oxidase activity and then may decrease reactive oxygen species [16]. Conversely, acute and severe hypercapnic acidosis has been shown to impair diaphragmatic contractile properties both in vitro [17-19] and in vivo [17,20].

Because reactive oxygen species production and the NF$\kappa \mathrm{B}$ pathway play major roles in VIDD [2] and because these pathways can be modulated with hypercapnic acidosis, we conducted an animal study and compared the effects of moderate and prolonged hypercapnic acidosis (72 continuous hours) versus normocapnia in a totally controlled mechanically ventilated healthy piglet model on in vivo VIDD. Our hypothesis was that moderate and prolonged hypercapnic acidosis may protect the diaphragm against VIDD.

\section{Materials and methods}

The study followed the guidelines for animal experiments established by the institutional animal care committee (INSERM U 1046, Montpellier, France) and the recommendations of the Helsinki Declaration.

\section{Animal preparation}

We used the same experimental design described in our previous studies $[17,21,22]$. In brief, 12 piglets ( 15 to $20 \mathrm{~kg}$ ) were anesthetized with intravenous pentobarbital sodium (5 to $6 \mathrm{mg} / \mathrm{kg}$ ). Piglets had their tracheas intubated with a cuffed endotracheal tube, and anesthesia was maintained with continuous intravenous propofol, midazolam, and ketamine without neuromuscular blocking agents. The depth of anesthesia was monitored with bispectral index (BIS; Aspect, Norwood, MA, USA) [23] and was adjusted to block the respiratory drive in both groups. The absence of spontaneous breathing was checked on the ventilator trend graphs, and electromyographic activity of the diaphragm was recorded in a few animals to confirm the absence of electrical activity $[17,22]$.
Volume-controlled ventilation was performed by using an ICU ventilator (Galileo; Hamilton Medical AG, Rhazuns, Switzerland). The following ventilator settings were determined to achieve normocapnia and were maintained throughout the whole experiment: inspired fraction of oxygen $\left(\mathrm{FiO}_{2}\right), 0.35$; tidal volume (TV), 10 to $12 \mathrm{ml} / \mathrm{kg}$; respiratory rate (RR), 15 to 30 cycles per minute; and positive end-expiratory pressure (PEEP), $5 \mathrm{~cm} \mathrm{H}_{2} \mathrm{O}$. An oral gastric tube and a bladder catheter were placed. Heating pads were used as needed to maintain a normal body temperature of $38.5^{\circ} \mathrm{C}$ to $39.5^{\circ} \mathrm{C}$. Parenteral nutrition was given from the first day, providing 30 to $35 \mathrm{kcal} / \mathrm{kg}$ per day. The animals received prophylactic intravenous antibiotics 3 times daily (amoxicillin-clavulanate, $100 \mathrm{mg} / \mathrm{kg}$ per day).

After surgical preparation of the right carotid artery, a carotid arterial line (PiCCO; Pulsion, Munich, Germany) was inserted for monitoring of the heart rate, arterial blood pressure, and cardiac output. Arterial and end-tidal $\mathrm{CO}_{2}$ partial pressure were checked with a capnograph (Deltatrac; Datex-Ohmeda, Helsinki, Finland) each 4 hours and with arterial blood gases each 12 hours (iSTAT; Abbott, Abbott Park, IL, USA).

A physician provided round-the-clock supervision and animal care for the entire duration of the study. The two groups received the same care, except for the level of capnia.

\section{Ventilatory care}

Animals were separated into two groups in which studied variables were measured each 12 hours: a control group $(n=6)$, mechanically ventilated in normocapnia without any intervention, and a hypercapnia group $(n=6)$, exposed to a determined level of moderate hypercapnic acidosis over a prolonged period. In the hypercapnia group, we increased the instrumental dead space, without any modifications of tidal volume or respiratory rate, to maintain the $\mathrm{PaCO}_{2}$ in the range of 55 to $70 \mathrm{~mm} \mathrm{Hg}$.

\section{Assessment of diaphragm muscle activity during mechanical ventilation In vivo assessment of transdiaphragmatic pressure}

Every 12 hours, we measured transdiaphragmatic pressure (Pdi) to assess in vivo diaphragmatic contractile force in both groups, as described in previous studies $[17,22]$. In brief, double air-filled balloon-tipped catheters were placed transorally into the distal third of the esophagus and in the stomach for measurement of Pdi. Bipolar transvenous pacing catheters were introduced via each internal jugular vein and adjusted to achieve stimulation of the phrenic nerve and subsequent contraction of the diaphragm. Pdi was produced by supramaximal stimulation at frequencies of $20,40,60,80,100$, and $120 \mathrm{~Hz}$ in a serial manner. Each train of impulses lasted of 2,000 $\mathrm{ms}$, and each pulse had duration of $150 \mathrm{~ms}$. A pressure- 
frequency curve was obtained for both groups at each 12$h$ period and were then compared.

\section{Statistical analysis}

Data are presented as mean $\pm \mathrm{SD}$, unless specifically indicated. Normality of the distribution was assessed with the Kolmogorov-Smirnov test.

Comparison of several means was performed by using a repeated-measures analysis of variance and the NewmanKeuls test. A two-way analysis of variance with time (HO, $\mathrm{H} 12, \mathrm{H} 24, \ldots$, to H72) as one factor and modality (normocapnia versus hypercapnia) as the other factor was used. When appropriate, a post hoc PLSD Fisher test was used. Nonparametric paired Wilcoxon tests were used to compare data from days 1 and 3 for each animal in both Normocapnia and Hypercapnia groups. All $P$ values were two-tailed and a $P$ value $<0.05$ was considered significant (StatView, version 5.0; SAS Institute Inc., Berkeley, CA, USA).

\section{Results}

Systemic and biologic response to mechanical ventilation Long-term mechanical ventilation (that is, 72 hours), either in normocapnia or hypercapnia, did not have consequences on body weight, intestinal transit, diuresis (data not shown) or hemodynamic variables (Table 1). Hypercapnia was associated with an increased cardiac output over time, mainly related to the increase of heart rate. Ventilator parameters were comparable among groups. Surprisingly, $\mathrm{PaO}_{2}$ was higher in the Hypercapnia group than in the Normocapnia group, although none of the piglets was hypoxemic. We did not observe any significant differences between the Normocapnia and Hypercapnia groups for all the studied baseline variables. Although BIS values were not significantly different between Normocapnia and Hypercapnia groups ( $38 \pm 8$ versus $42 \pm 12$; $P$ > $0.99)$, mean midazolam-level administration remained at a higher level in the Hypercapnia group $(5.1 \pm 0.6 \mathrm{mg} / \mathrm{h})$ than in the Normocapnia group $(3.5 \pm 0.6 \mathrm{mg} / \mathrm{h})$ during the study $(P<0.05$ between Normocapnia and Hypercapnia groups after 12 hours of ventilation). Doses of propofol were higher in the Hypercapnia group in comparison with the Normocapnia group $(102 \pm 8 \mathrm{mg} / \mathrm{h}$ and $135 \pm 49$ $\mathrm{mg} / \mathrm{h}$ in Normocapnia and Hypercapnia groups, respectively, $P<0.05$ after 12 hours of ventilation).

\section{In vivo assessment of diaphragmatic force}

The baseline pressure-frequency curves of the two groups were not significantly different (Pdi at $20 \mathrm{~Hz}=32.7 \pm 8.7$ $\mathrm{cm} \mathrm{H}_{2} \mathrm{O}$ versus $34.4 \pm 8.4 \mathrm{~cm} \mathrm{H} \mathrm{H}_{2} \mathrm{O}$; and at $120 \mathrm{~Hz}=56.8$ $\pm 8.7 \mathrm{~cm} \mathrm{H}_{2} \mathrm{O}$ versus $60.8 \pm 5.7 \mathrm{~cm} \mathrm{H}_{2} \mathrm{O}$, for Normocapnia and Hypercapnia groups, respectively) (Figure 1A and $1 \mathrm{~B})$.
Although Pdi decreased significantly in the Normocapnia group between baseline and $\mathrm{H} 72$ at all frequencies except $20 \mathrm{~Hz}$ (Figure $1 \mathrm{~A})(P<0.05)$, it did not change significantly in the Hypercapnia group (Figure 1B). The force decreased significantly after 48 hours of mechanical ventilation in the Normocapnia group, whereas it remained stable in the Hypercapnia group (Figure 2A and $2 \mathrm{~B})$.

\section{Discussion}

This study shows that although prolonged totally controlled mechanical ventilation in normocapnia alters diaphragm contractility in vivo, maintaining a moderate hypercapnic acidosis during prolonged (72 continuous hours) controlled mechanical ventilation seems to prevent VIDD.

VIDD related to totally controlled mechanical ventilation has been well described, both in several animal studies [17,21,22,24-29] and recently in humans [4-8]. Maintaining diaphragm at rest in the present study (Normocapnia group) effectively promoted VIDD (Figure 1).

Hypercapnic acidosis is frequently observed in critically ill patients. Hypercapnic acidosis can be acute, and as such is often a consequence of an acute disease (acute respiratory failure, hypnotic or opioids overdose), or can be moderate and prolonged, as a consequence of a "protective setting" of mechanical ventilation. The physiologic consequences of hypercapnic acidosis on the brain and the cardiovascular system have been well described and include cerebral hypertension, pulmonary artery vasoconstriction, severe tachycardia, and coma [30,31]. Acute hypercapnic acidosis has been implicated in diaphragm dysfunction in animal studies [17,32-34] as well as in healthy human volunteers $[20,35,36]$. We recently reported that the recovery of diaphragm contractility impairment related to acute hypercapnic acidosis was incomplete 1 hour after the return to normocapnia [17]. This impairment was associated with the severity of the acidosis and might be partially reversed by inotropes such as dopamine [18] or dobutamine [19]. In opposition to severe and acute hypercapnic acidosis, beneficial effects of moderate hypercapnic acidosis ( $\mathrm{pH} 7.20$ to 7.30 and/or $\mathrm{PaCO}_{2} 50$ to $70 \mathrm{~mm} \mathrm{Hg}$ ) have been reported on lung inflammation during acute lung injury with or without bacterial pneumonia [13,37-39]. In addition, moderate hypercapnic acidosis may increase cardiac index without increasing oxygen consumption during septic shock [31]. However, few data concern the consequences of moderate hypercapnic acidosis on muscles, in particular, the diaphragm. In the present study, we report for the first time that moderate hypercapnic acidosis seems to prevent VIDD in comparison with normocapnia. Although totally controlled mechanical ventilation with 
Table 1 Hemodynamic and respiratory variables for the seven steps of measures between the Normocapnia $(n=6)$ and the Hypercapnia $(n=6)$ groups

\begin{tabular}{|c|c|c|c|c|c|c|c|}
\hline & $\mathrm{HO}$ & $\mathrm{H} 12$ & $\mathrm{H} 24$ & H36 & $\mathrm{H} 48$ & $\mathrm{H} 60$ & $\mathrm{H} 72$ \\
\hline \multicolumn{8}{|c|}{ Minute ventilation (L/min) } \\
\hline Normocapnia & $5.9 \pm 0.8$ & $4.4 \pm 0.6$ & $5.1 \pm 0.6$ & $4.9 \pm 0.5$ & $4.7 \pm 0.4$ & $4.8 \pm 0.6$ & $4.7 \pm 0.8$ \\
\hline Hypercapnia & $4.6 \pm 0.3$ & $4.3 \pm 0.1$ & $5.1 \pm 0.2$ & $4.8 \pm 0.3$ & $4.2 \pm 0.2$ & $4.8 \pm 0.2$ & $4.3 \pm 0.2$ \\
\hline \multicolumn{8}{|c|}{ Tidal volume (ml) } \\
\hline Normocapnia & $240 \pm 40$ & $220 \pm 20$ & $230 \pm 20$ & $230 \pm 25$ & $225 \pm 25$ & $230 \pm 25$ & $205 \pm 10$ \\
\hline Hypercapnia & $230 \pm 22$ & $225 \pm 15$ & $235 \pm 30$ & $240 \pm 15$ & $235 \pm 30$ & $230 \pm 20$ & $240 \pm 20$ \\
\hline \multicolumn{8}{|c|}{ Respiratory rate (c/min) } \\
\hline Normocapnia & $24 \pm 3$ & $20 \pm 3$ & $22 \pm 2$ & $22 \pm 2$ & $21 \pm 1$ & $21 \pm 1$ & $20 \pm 1$ \\
\hline Hypercapnia & $20 \pm 6$ & $19 \pm 5$ & $19 \pm 4$ & $20 \pm 3$ & $18 \pm 6$ & $19 \pm 4$ & $18 \pm 3$ \\
\hline \multicolumn{8}{|c|}{ Peak pressure $\left(\mathrm{cm} \mathrm{H}_{2} \mathrm{O}\right)$} \\
\hline Normocapnia & $22 \pm 1$ & $23 \pm 2$ & $22 \pm 1$ & $21 \pm 3$ & $23 \pm 2$ & $22 \pm 3$ & $23 \pm 3$ \\
\hline Hypercapnia & $22 \pm 3$ & $21 \pm 2$ & $20 \pm 2$ & $22 \pm 2$ & $20 \pm 3$ & $20 \pm 3$ & $20 \pm 2$ \\
\hline \multicolumn{8}{|c|}{ Plateau pressure $\left(\mathrm{cm} \mathrm{H}_{2} \mathrm{O}\right)$} \\
\hline Normocapnia & $14 \pm 2$ & $14 \pm 3$ & $13 \pm 2$ & $14 \pm 3$ & $13 \pm 2$ & $14 \pm 4$ & $15 \pm 2$ \\
\hline Hypercapnia & $13 \pm 1$ & $14 \pm 3$ & $12 \pm 3$ & $13 \pm 2$ & $12 \pm 4$ & $13 \pm 3$ & $13 \pm 3$ \\
\hline \multicolumn{8}{|l|}{$\mathrm{pH}$} \\
\hline Normocapnia & $7.52 \pm 0.02$ & $7.47 \pm 0.06$ & $7.46 \pm 0.04$ & $7.45 \pm 0.01$ & $7.44 \pm 0.04$ & $7.47 \pm 0.04$ & $7.44 \pm 0.05$ \\
\hline Hypercapnia & $7.43 \pm 0.07$ & $7.31 \pm 0.09^{\mathrm{ab}}$ & $7.29 \pm 0.05^{\mathrm{ab}}$ & $7.30 \pm 0.06^{\mathrm{ab}}$ & $7.27 \pm 0.07^{\mathrm{ab}}$ & $7.25 \pm 0.08^{\mathrm{ab}}$ & $7.22 \pm 0.04^{\mathrm{ab}}$ \\
\hline \multicolumn{8}{|l|}{$\mathrm{PaO}_{2}(\mathrm{~mm} \mathrm{Hg})$} \\
\hline Normocapnia & $99 \pm 8$ & $97 \pm 6$ & $95 \pm 5$ & $98 \pm 3$ & $95 \pm 6$ & $97 \pm 5$ & $101 \pm 6$ \\
\hline Hypercapnia & $147 \pm 8^{a}$ & $148 \pm 5^{a}$ & $149 \pm 4^{a}$ & $132 \pm 4^{a}$ & $115 \pm 8^{a}$ & $146 \pm 6^{a}$ & $110 \pm 9$ \\
\hline \multicolumn{8}{|l|}{$\mathrm{PaCO}_{2}(\mathrm{~mm} \mathrm{Hg})$} \\
\hline Normocapnia & $33 \pm 6$ & $39 \pm 3$ & $41 \pm 3$ & $40 \pm 3$ & $39 \pm 3$ & $38 \pm 2$ & $37 \pm 3$ \\
\hline Hypercapnia & $44 \pm 7^{\mathrm{a}}$ & $65 \pm 8^{\mathrm{ab}}$ & $70 \pm 3^{\mathrm{ab}}$ & $77 \pm 8^{\mathrm{ab}}$ & $73 \pm 10^{\mathrm{ab}}$ & $66 \pm 7^{\mathrm{ab}}$ & $73 \pm 4^{\mathrm{ab}}$ \\
\hline \multicolumn{8}{|l|}{$\mathrm{SaO}_{2}(\%)$} \\
\hline Normocapnia & $98 \pm 2$ & $99 \pm 2$ & $97 \pm 3$ & $100 \pm 2$ & $98 \pm 2$ & $97 \pm 3$ & $96 \pm 4$ \\
\hline Hypercapnia & $99 \pm 2$ & $98 \pm 1$ & $97 \pm 4$ & $99 \pm 2$ & $99 \pm 4$ & $98 \pm 3$ & $99 \pm 3$ \\
\hline \multicolumn{8}{|c|}{ Plasma bicarbonate $(\mathrm{mM})$} \\
\hline Normocapnia & $27 \pm 4$ & $29 \pm 4$ & $29 \pm 5$ & $29 \pm 3$ & $27 \pm 3$ & $30 \pm 2$ & $26 \pm 2$ \\
\hline Hypercapnia & $28 \pm 4$ & $35 \pm 5^{\mathrm{ab}}$ & $33 \pm 3^{\mathrm{ab}}$ & $35 \pm 2^{\mathrm{ab}}$ & $34 \pm 5^{\mathrm{ab}}$ & $32 \pm 4^{b}$ & $32 \pm 5^{\mathrm{ab}}$ \\
\hline \multicolumn{8}{|c|}{ Heart rate $(\mathrm{c} / \mathrm{min})$} \\
\hline Normocapnia & $101 \pm 10$ & $106 \pm 12$ & $107 \pm 12$ & $103 \pm 10$ & $97 \pm 8$ & $101 \pm 14$ & $101 \pm 15$ \\
\hline Hypercapnia & $93 \pm 18$ & $96 \pm 27$ & $91 \pm 26$ & $118 \pm 26^{\mathrm{ab}}$ & $123 \pm 12^{\mathrm{ab}}$ & $118 \pm 12^{\mathrm{ab}}$ & $114 \pm 16^{\mathrm{ab}}$ \\
\hline \multicolumn{8}{|c|}{ Mean blood pressure $(\mathrm{mm} \mathrm{Hg})$} \\
\hline Normocapnia & $75 \pm 7$ & $80 \pm 10$ & $88 \pm 7$ & $86 \pm 9$ & $84 \pm 13$ & $83 \pm 13$ & $88 \pm 14$ \\
\hline Hypercapnia & $83 \pm 15$ & $72 \pm 14$ & $76 \pm 16$ & $87 \pm 18$ & $86 \pm 22$ & $79 \pm 15$ & $77 \pm 15$ \\
\hline \multicolumn{8}{|c|}{ Cardiac Output (I/min) } \\
\hline Normocapnia & $2.2 \pm 0.3$ & $2.7 \pm 0.3$ & $2.8 \pm 0.5$ & $2.8 \pm 0.2$ & $2.7 \pm 0.2$ & $2.7 \pm 0.2$ & $2.7 \pm 0.3$ \\
\hline Hypercapnia & $2.8 \pm 0.4$ & $2.9 \pm 0.6$ & $3.1 \pm 0.6$ & $3.8 \pm 0.5^{\mathrm{ab}}$ & $3.3 \pm 0.7^{\mathrm{ab}}$ & $3.2 \pm 0.6^{\mathrm{ab}}$ & $3.4 \pm 0.7^{\mathrm{ab}}$ \\
\hline \multicolumn{8}{|c|}{ Stroke volume (ml) } \\
\hline Normocapnia & $22 \pm 7$ & $27 \pm 10$ & $27 \pm 11$ & $28 \pm 8$ & $29 \pm 10$ & $27 \pm 11$ & $26 \pm 12$ \\
\hline Hypercapnia & $28 \pm 8$ & $29 \pm 12$ & $32 \pm 9$ & $28 \pm 14$ & $27 \pm 8$ & $27 \pm 10$ & $30 \pm 8$ \\
\hline
\end{tabular}

Data are expressed as mean \pm SD. ${ }^{\mathrm{a}} P<0.05$ between Normocapnia and Hypercapnia groups; ${ }^{\mathrm{b}} p<0.05$ intragroup difference between time considered and baseline. $\mathrm{PaO}_{2}$, arterial pressure of oxygen; $\mathrm{PaCO}_{2}$, arterial pressure of carbon dioxide; $\mathrm{SaO}_{2}$, oxygen saturation of arterial blood.

normocapnia during 72 continuous hours led to a $25 \%$ decrease of Pdi, evaluated in vivo (Figure 1), no significant differences existed between baseline and H72 in the moderate hypercapnic acidosis group. The mechanisms of VIDD related to totally controlled mechanical ventilation have been well described in several animal models, including piglets $[22,24,40,41]$. The main mechanisms include the stimulation of proteolysis, apoptosis oxidative stress, protein synthesis impairment, autophagy, and sarcomeric lesions $[17,28,40-44]$. Although those mechanisms have been well explored, very few countermeasures have been reported. Those countermeasures include 


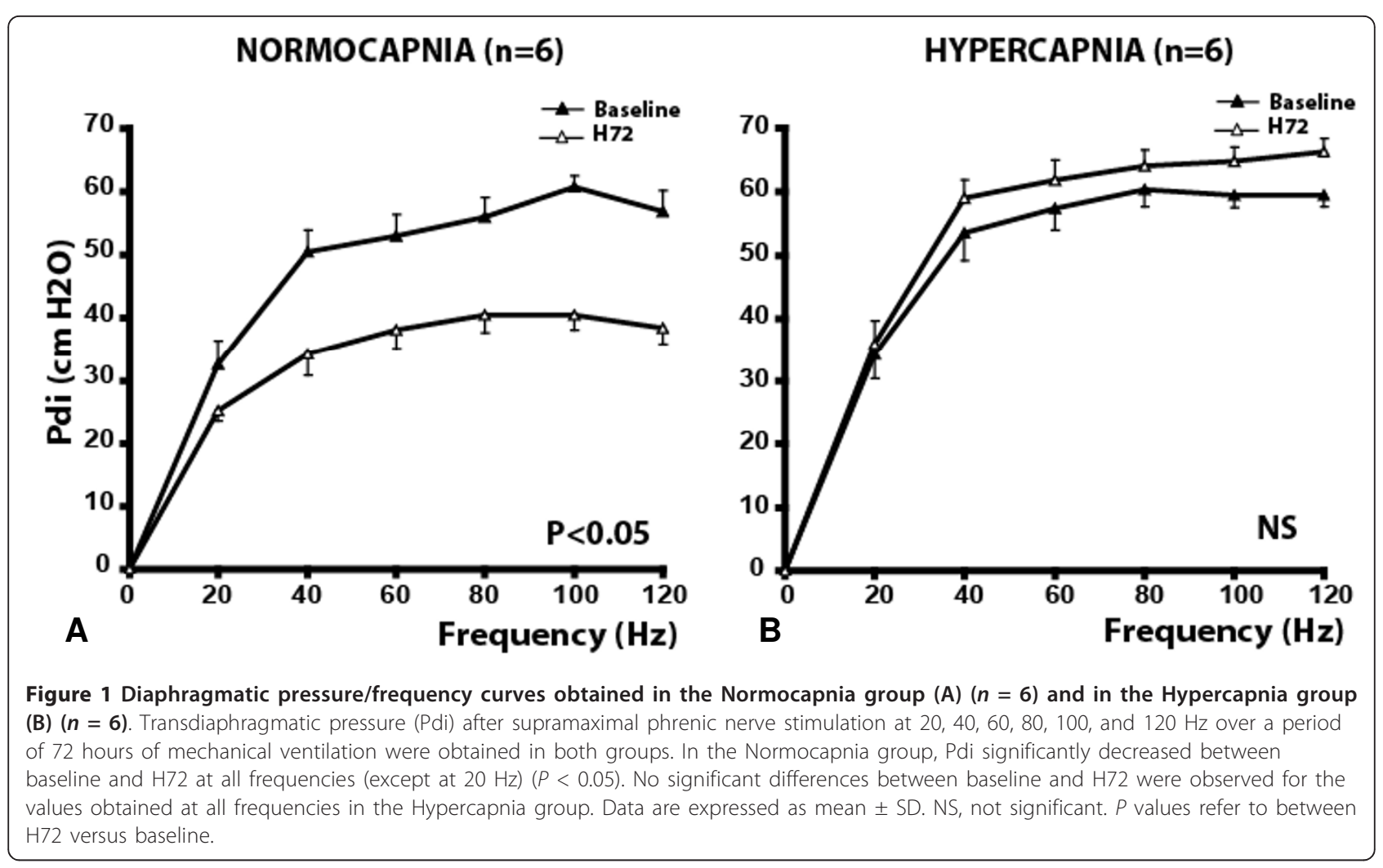

pharmacologic interventions, such as antioxidative molecules [45-48] or high-dose steroids [49], but also ventilatory measures, such as maintaining spontaneous ventilatory cycles during mechanical ventilation [50-52].
The present study reports that moderate and prolonged hypercapnic acidosis decreases the diaphragm impairment related to prolonged totally controlled mechanical ventilation. The mechanism of the observed

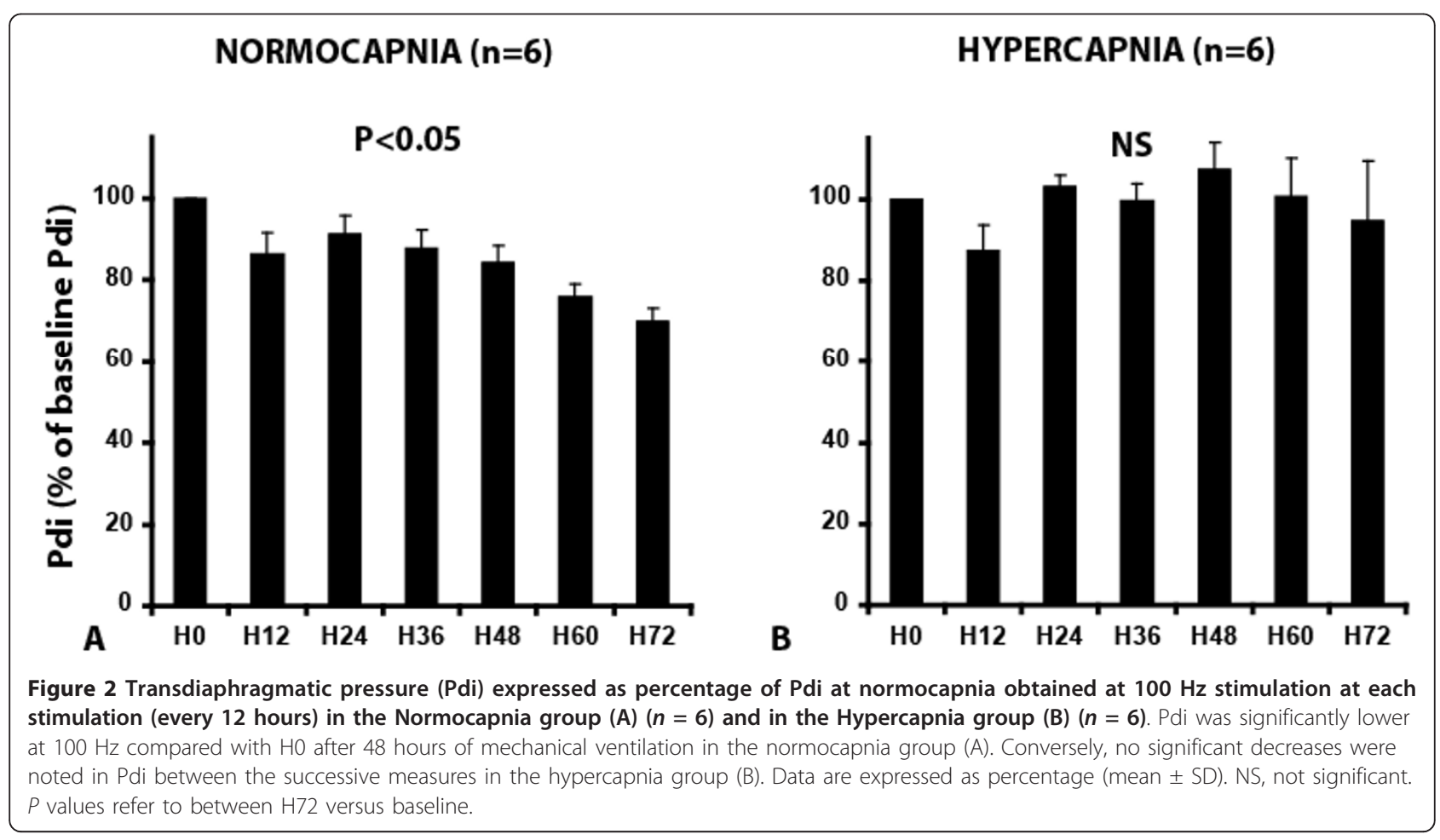


"protective" effect of moderate and prolonged acute hypercapnic acidosis is not known and was not explored in the present study.

In the present study, hypercapnic acidosis was associated with an increased cardiac output, even with higher doses of anesthetic drugs (Table 1). Mechanical ventilation perse has been reported to impair diaphragm blood flow [53], and whether prolonged and moderate hypercapnic acidosis may prevent this impairment has not been studied. We can speculate that one of the hypothetical mechanisms could be better diaphragm perfusion, although we did not measure the diaphragm blood flow. Another potential mechanism that might have played a role is the increased oxygen delivery to the tissues due to hypercapnic acidosis $[54,55]$. Moderate hypercapnic acidosis has been demonstrated to possess potent antioxidant properties in the lung, both in vitro and in vivo [14,16,38], by using biomarkers such as isoprostane or the in vitro generation of uric acid from addition of xanthine oxidase to purine in an isolated buffer-perfused rabbit lung [16]. Furthermore, hypocapnic alkalosis significantly increased $\mathrm{H}_{2} \mathrm{O}_{2}$-induced apoptosis and caspase activation of A549 lung cells [56], suggesting that hypocapnic alkalosis may intensify oxidative-induced apoptosis of alveolar epithelial cells via increasing cytosol level of calcium, a strong stimulus of calpain- and caspase-related proteolysis. Regarding those studies, we could speculate that moderate hypercapnic acidosis may inhibit calcium-dependent proteases, thereby limiting the extent of atrophy related to prolonged controlled mechanical ventilation. Moderate hypercapnic acidosis may also promote the transition from glycolytic, type II fibers to type I fibers after several days of hypercapnic acidosis exposure in an animal model [57]. Recently and in opposition to normocapnia, moderate hypercapnia $\left(\mathrm{PaCO}_{2}\right.$ equal to $\left.75 \mathrm{~mm} \mathrm{Hg}\right)$ during an 18 -hour period of mechanical ventilation in rats was associated with a higher diaphragmatic force, a decrease in diaphragmatic IL-6 and KC pro-inflammatory cytokines, and an increase in diaphragmatic antiinflammatory cytokine IL-10 level [58]. Another well-known effect of moderate hypercapnic acidosis is the inhibition of inflammation process related to mechanical ventilation in healthy or acutely injured lungs $[13,38]$.

Some study limitations must be pointed out. First, we did not compare our results with a control group without anesthesia, or mechanical ventilation, because large animals must be anesthetized for procedures such as phrenic stimulation and Pdi recording.

Second, in the hypercapnia group, to obtain a similar sedation level and to neutralize the centers of breathing, higher levels of propofol and midazolam doses were required. Therefore, we cannot eliminate a direct effect of sedation on Pdi. However, in the clinical situation, sedation is frequently necessary to ensure patient/ventilator synchrony with the controlled mechanical ventilation mode. Although this point clearly represents a methodologic limit of our study, it reflects the clinical interaction between sedation and mechanical ventilation.

Third, $\mathrm{PaO}_{2}$ values in the hypercapnia group were slightly above the $\mathrm{PaO}_{2}$ levels in the normocapnia group. However, because mean $\mathrm{PaO}_{2}$ in the normocapnia group was $350 \mathrm{~mm} \mathrm{Hg}$, it is doubtful that this could represent the leading cause of the protective effect observed in the hypercapnia group.

Finally, we do not provide mechanistic analysis for this study.

\section{Conclusions}

The present study reports that prolonged and moderate hypercapnic acidosis may protect against VIDD in a totally controlled mechanically ventilated piglet model.

\section{Key messages}

- Prolonged controlled mechanical ventilation with normocapnia is associated with a diaphragm contractility impairment and ventilator-induced diaphragmatic dysfunction.

- In opposition, prolonged ventilation with moderate hypercapnic acidosis seems to prevent VIDD in a 72-hour healthy piglet study.

\section{Authors' contributions}

$\mathrm{BJ}, \mathrm{SM}$, and SJ designed the study protocol and wrote the report. CLG, MS, and $\mathrm{NR}$ helped in performing the experiments. GC, EF, and JMC helped in correcting the report. All authors read and approved the manuscript for publication.

\section{Competing interests}

BJ received speaking fees from Merck, not in relation to the present study. EF received speaking fees from GE HealthCare, and from Fresenius Kabi, not in relation to the present study. JMC received speaking fees from LFB, Fresenius Kabi, Merck, Baxter, Draeger, and GE HealthCare, not in relation to the present study. SJ received research grants and speaking fees from Maquet, Draeger, Hamilton Medical, Fisher Paykel, Abbott, not in relation to the present study. Other co-authors have none to declare. Hamilton Medical AG, Rhäzüns, Switzerland supported us, in part, by furnishing the Galileo ventilator.

\section{Acknowledgements}

The authors thank Patrick McSweeny for his English editing.

\section{Author details}

${ }^{1}$ Intensive Care Unit, Department of Anaesthesia and Critical Care, Saint Eloi Teaching Hospital and Institut National de la Santé et de la Recherche Médicale Unit 1046 (INSERM U-1046), Université Montpellier 1, 34295 Montpellier, France. ${ }^{2}$ Department of Emergency Medicine, Lapeyronie Teaching Hospital, Université Montpellier 1, 34295 Montpellier, France. ${ }^{3}$ Department of Anesthesiology and Critical Care, Clermont Ferrand University Hospital F-63000, France.

Received: 12 September 2012 Revised: 29 October 2012 Accepted: 7 January 2013 Published: 24 January 2013 


\section{References}

1. Haitsma JJ: Diaphragmatic dysfunction in mechanical ventilation. Curr Opin Anaesthesiol 2011, 24:214-218.

2. Jaber $S$, Jung B, Matecki S, Petrof B: Ventilator induced diaphragm dysfunction: humans studies confirm animal models! Crit Care 2011 15:206.

3. Petrof BJ, Jaber S, Matecki S: Ventilator-induced diaphragmatic dysfunction. Curr Opin Crit Care 2010, 16:19-25.

4. Hermans G, Agten A, Testelmans D, Decramer M, Gayan-Ramirez G. Increased duration of mechanical ventilation is associated with decreased diaphragmatic force: a prospective observational study. Crit Care 2010, 14:R127.

5. Hussain SN, Mofarrahi M, Sigala I, Kim HC, Vassilakopoulos T, Maltais F, Bellenis I, Chaturvedi R, Gottfried SB, Metrakos P, Danialou G, Matecki S, Jaber S, Petrof BJ, Goldberg P: Mechanical ventilation-induced diaphragm disuse in humans triggers autophagy. Am J Respir Crit Care Med 2010, 182:1377-1386

6. Jaber S, Petrof BJ, Jung B, Chanques G, Berthet JP, Rabuel C, Bouyabrine $H$, Courouble $P$, Koechlin $C$, Sebbane M, Similowski T, Scheuermann V, Mebazaa A, Capdevila X, Mornet D, Mercier J, Lacampagne A, Philips A, Matecki S: Rapidly progressive diaphragmatic weakness and injury during mechanical ventilation in humans. Am J Respir Crit Care Med 2011, 183:364-371.

7. Levine S, Biswas C, Dierov J, Barsotti R, Shrager JB, Nguyen T, Sonnad S, Kucharchzuk JC, Kaiser LR, Singhal S, Budak MT: Increased proteolysis, myosin depletion and atrophic AKT-FOXO signaling in human diaphragm disuse. Am J Respir Crit Care Med 2011, 183:483-490.

8. Levine S, Nguyen T, Taylor N, Friscia ME, Budak MT, Rothenberg P, Zhu J, Sachdeva R, Sonnad S, Kaiser LR, Rubinstein NA, Powers SK, Shrager JB: Rapid disuse atrophy of diaphragm fibers in mechanically ventilated humans. N Engl J Med 2008, 358:1327-1335.

9. Ricard JD, Dreyfuss D, Saumon G: Ventilator-induced lung injury. Eur Respir J Supp/ 2003, 42:2s-9s.

10. Bigatello LM, Pesenti $A$ : Ventilator-induced lung injury: less ventilation, less injury. Anesthesiology 2009, 111:699-700

11. Pelosi P, Rocco PR: Ventilator-induced lung injury in healthy and diseased lungs: better to prevent than cure! Anesthesiology 2011, 115:923-925

12. The Acute Respiratory Distress Syndrome Network: Ventilation with lower tidal volumes as compared with traditional tidal volumes for acute lung injury and the acute respiratory distress syndrome. N Engl J Med 2000 342:1301-1308

13. Laffey JG, O'Croinin D, McLoughlin P, Kavanagh BP: Permissive hypercapnia: role in protective lung ventilatory strategies. Intensive Care Med 2004, 30:347-356.

14. Kantores C, McNamara PJ, Teixeira L, Engelberts D, Murthy P, Kavanagh BP, Jankov RP: Therapeutic hypercapnia prevents chronic hypoxia-induced pulmonary hypertension in the newborn rat. Am J Physiol Lung Cell Mol Physiol 2006, 291:L912-L922.

15. Takeshita K, Suzuki Y, Nishio K, Takeuchi O, Toda K, Kudo H, Miyao N, Ishii M, Sato N, Naoki K, Aoki T, Suzuki K, Hiraoka R, Yamaguchi K: Hypercapnic acidosis attenuates endotoxin-induced nuclear factor[kappa]B activation. Am J Respir Cell Mol Biol 2003, 29:124-132.

16. Shibata K, Cregg N, Engelberts D, Takeuchi A, Fedorko L, Kavanagh BP: Hypercapnic acidosis may attenuate acute lung injury by inhibition of endogenous xanthine oxidase. Am J Respir Critical Care Med 1998, 158:1578-1584.

17. Jaber S, Jung B, Sebbane M, Ramonatxo M, Capdevila X, Mercier Eledjam JJ, Matecki S: Alteration of the piglet diaphragm contractility in vivo and its recovery after acute hypercapnia. Anesthesiology 2008, 108:651-658

18. Fujii Y: Comparative effects of dopamine and dobutamine on hypercapnic depression of diaphragmatic contractility in dogs. Pulm Pharmacol Ther 2004, 17:289-292.

19. Fujii $Y$, Uemura $A$ : The effects of different dobutamine infusion rates on hypercapnic depression of diaphragmatic contractility in pentobarbitalanesthetized dogs. Anesth Analg 2007, 105:1379-1384, table of contents.

20. Rafferty GF, Lou Harris M, Polkey MI, Greenough A, Moxham J: Effect of hypercapnia on maximal voluntary ventilation and diaphragm fatigue in normal humans. Am J Respir Crit Care Med 1999, 160:1567-1571.
21. Jung B, Constantin JM, Rossel N, Le Goff C, Sebbane M, Coisel Y, Chanques G, Futier E, Hugon G, Capdevila X, Petrof B, Matecki S, Jaber S: Adaptive support ventilation prevents ventilator-induced diaphragmatic dysfunction in piglet: an in vivo and in vitro study. Anesthesiology 2010, 112:1435-1443.

22. Jaber S, Sebbane M, Koechlin C, Hayot M, Capdevila X, Eledjam JJ, Prefaut C, Ramonatxo M, Matecki S: Effects of short vs. prolonged mechanical ventilation on antioxidant systems in piglet diaphragm. Intensive Care Med 2005, 31:1427-1433.

23. Vivien B, Di Maria S, Ouattara A, Langeron O, Coriat P, Riou B: Overestimation of bispectral index in sedated intensive care unit patients revealed by administration of muscle relaxant. Anesthesiology 2003, 99:9-17.

24. Anzueto A, Peters JI, Tobin MJ, de los Santos R, Seidenfeld JJ, Moore G, Cox WJ, Coalson JJ: Effects of prolonged controlled mechanical ventilation on diaphragmatic function in healthy adult baboons. Critical Care Med 1997, 25:1187-1190

25. Gayan-Ramirez G, Decramer M: Effects of mechanical ventilation on diaphragm function and biology. Eur Respir J 2002, 20:1579-1586.

26. Jaber S, Sebbane M, Verzilli D, Matecki S, Wysocki M, Eledjam JJ, Brochard L: Adaptive support and pressure support ventilation behavior in response to increased ventilatory demand. Anesthesiology 2009, 110:620-627.

27. Mrozek S, Jung B, Petrof B, Pauly M, Roberge S, Lacampagne A, Cassan C, Thireau J, Molinari N, Futier E, Scheuermann V, Constantin JM, Matecki S, Jaber S: Ventilator-induced diaphragmatic dysfunction: development and perspectives of the first mouse model. Anesthesiology 2012, 117:560-567.

28. Powers SK, Shanely RA, Coombes JS, Koesterer TJ, McKenzie M, Van Gammeren D, Cicale M, Dodd SL: Mechanical ventilation results in progressive contractile dysfunction in the diaphragm. J Appl Physiol 2002, 92:1851-1858.

29. Yang L, Luo J, Bourdon J, Lin MC, Gottfried SB, Petrof BJ: Controlled mechanical ventilation leads to remodeling of the rat diaphragm. Am J Respir Crit Care Med 2002, 166:1135-1140.

30. Michelet P: Hypercapnic acidosis: how far? Anesthesiology 2008, 109:771-772

31. Wang Z, Su F, Bruhn A, Yang X, Vincent JL: Acute hypercapnia improves indices of tissue oxygenation more than dobutamine in septic shock. Am J Respir Crit Care Med 2008, 177:178-183.

32. Mador MJ, Wendel T, Kufel TJ: Effect of acute hypercapnia on diaphragmatic and limb muscle contractility. Am J Respir Crit Care Med 1997, 155:1590-1595.

33. Schnader J, Howell S, Fitzgerald RS, Roussos C: Interaction of fatigue and hypercapnia in the canine diaphragm. J Appl Physiol 1988, 64:1636-1643.

34. Yanos J, Wood LD, Davis K, Keamy M: The effect of respiratory and lactic acidosis on diaphragm function. Am Rev Respir Dis 1993, 147:616-619.

35. Jonville $S$, Delpech N, Denjean A: Contribution of respiratory acidosis to diaphragmatic fatigue at exercise. Eur Respir J 2002, 19:1079-1086.

36. Juan G, Calverley P, Talamo C, Schnader J, Roussos C: Effect of carbon dioxide on diaphragmatic function in human beings. N Engl J Med 1984, 310:874-879.

37. Chonghaile MN, Higgins BD, Costello J, Laffey JG: Hypercapnic acidosis attenuates lung injury induced by established bacterial pneumonia. Anesthesiology 2008, 109:837-848.

38. Laffey JG, Honan D, Hopkins N, Hyvelin JM, Boylan JF, McLoughlin P: Hypercapnic acidosis attenuates endotoxin-induced acute lung injury. Am J Respir Crit Care Med 2004, 169:46-56.

39. Ni Chonghaile M, Higgins B, Laffey JG: Permissive hypercapnia: role in protective lung ventilatory strategies. Curr Opin Crit Care 2005, 11:56-62

40. Petrof BJ, Jaber S, Matecki S: Ventilator-induced diaphragmatic dysfunction. Curr Opin Crit Care 2010, 16:19-25.

41. Sassoon CS: Ventilator-associated diaphragmatic dysfunction. Am J Resp Crit Care Med 2002, 166:1017-1018.

42. Gayan-Ramirez GN, Decramer ML: Diaphragm antioxidant system in controlled mechanical ventilation in piglets: short term vs. prolonged mechanical ventilation response. Intensive Care Med 2005, 31:1303-1305.

43. Powers SK, Kavazis AN, McClung JM: Oxidative stress and disuse muscle atrophy. J Appl Physiol 2007, 102:2389-2397.

44. Vassilakopoulos T: Ventilator-induced diaphragm dysfunction: the clinical relevance of animal models. Intensive Care Med 2008, 34:7-16. 
45. Maes K, Testelmans D, Powers S, Decramer M, Gayan-Ramirez G: Leupeptin inhibits ventilator-induced diaphragm dysfunction in rats. Am J Respir Crit Care Med 2007, 175:1134-1138.

46. MCClung JM, Kavazis AN, Whidden MA, DeRuisseau KC, Falk DJ, Criswell DS, Powers SK: Antioxidant administration attenuates mechanical ventilationinduced rat diaphragm muscle atrophy independent of protein kinase $B$ (PKB Akt) signalling. J Physiol 2007, 585:203-215.

47. Oliveira GP, Oliveira MB, Santos RS, Lima LD, Dias CM, Ab' Saber AM, Teodoro WR, Capelozzi VL, Gomes RN, Bozza PT, Pelosi P, Rocco PR: Intravenous glutamine decreases lung and distal organ injury in an experimental model of abdominal sepsis. Crit Care 2009, 13:R74.

48. Supinski GS, Vanags J, Callahan LA: Eicosapentaenoic acid preserves diaphragm force generation following endotoxin administration. Crit Care 2010, 14:R35.

49. Maes K, Testelmans D, Cadot P, Deruisseau K, Powers SK, Decramer M, Gayan-Ramirez G: Effects of acute administration of corticosteroids during mechanical ventilation on rat diaphragm. Am J Respir Crit Care Med 2008, 178:1219-1226.

50. Futier E, Constantin JM, Combaret L, Mosoni L, Roszyk L, Sapin V, Attaix D, Jung B, Jaber S, Bazin JE: Pressure support ventilation attenuates ventilator-induced protein modifications in the diaphragm. Crit Care 2008, 12:R116.

51. Gayan-Ramirez G, Testelmans D, Maes K, Racz GZ, Cadot P, Zador E, Wuytack F, Decramer M: Intermittent spontaneous breathing protects the rat diaphragm from mechanical ventilation effects. Crit Care Med 2005, 33:2804-2809.

52. Sassoon CS, Zhu E, Caiozzo VJ: Assist-control mechanical ventilation attenuates ventilator-induced diaphragmatic dysfunction. Am J Respir Crit Care Med 2004, 170:626-632.

53. Davis RT, Bruells CS, Stabley JN, McCullough DJ, Powers SK, Behnke BJ Mechanical ventilation reduces rat diaphragm blood flow and impairs oxygen delivery and uptake. Crit Care Med 2012, 40:2858-2866.

54. Ratnaraj J, Kabon B, Talcott MR, Sessler DI, Kurz A: Supplemental oxygen and carbon dioxide each increase subcutaneous and intestinal intramural oxygenation. Anesth Analg 2004, 99:207-211.

55. Akca O, Doufas AG, Morioka N, Iscoe S, Fisher J, Sessler DI: Hypercapnia improves tissue oxygenation. Anesthesiology 2002, 97:801-806.

56. Ando T, Mikawa K, Nishina K, Misumi T, Obara H: Hypocapnic alkalosis enhances oxidant-induced apoptosis of human alveolar epithelial type II cells. J Int Med Res 2007, 35:118-126.

57. Kumagai M, Kondo T, Ohta Y, Ishihara T: Size and composition changes in diaphragmatic fibers in rats exposed to chronic hypercapnia. Chest 2001, 119:565-571.

58. Schellekens WJ, van Hees HW, Andrade Acuna GL, Linkels M, van der Hoeven JG, Dekhuijzen PN, Scheffer GJ, Heunks LM: Hypercapnia attenuates mechanical ventilation-induced diaphragm atrophy and dysfunction. Am J Respir Crit Care Med 2011, 183:A4249.

doi:10.1186/cc12486

Cite this article as: Jung et al: Moderate and prolonged hypercapnic acidosis may protect against ventilator-induced diaphragmatic dysfunction in healthy piglet: an in vivo study. Critical Care 2013 17:R15.

\section{Submit your next manuscript to BioMed Central and take full advantage of:}

- Convenient online submission

- Thorough peer review

- No space constraints or color figure charges

- Immediate publication on acceptance

- Inclusion in PubMed, CAS, Scopus and Google Scholar

- Research which is freely available for redistribution 